DOI: https://doi.org/10.24127/ajpm.v10i2.3562

\title{
KOMPARASI PENGARUH PENDEKATAN SCIENTIFIC DAN OPEN-ENDED TERHADAP KEMAMPUAN LITERASI MATEMATIS SISWA MENENGAH PERTAMA DI KEFAMENANU
}

\author{
Fitriani $^{{ }^{*}}$, Cecilia Novianti Salsinha ${ }^{2}$ \\ ${ }^{1 *, 2}$ Universitas Timor, Kefamenanu, Indonesia \\ * Corresponding author. Jl. Km 9 Kelurahan Sasi 85616,TTU-NTT, Indonesia. \\ E-mail: $\quad$ bhrfitriani@gmail.com ${ }^{1 *}$ \\ ceciliasalsinha@unimor.ac.id $^{2)}$
}

Received 14 February 2021; Received in revised form 19 June 2021; Accepted 01 July 2021

\begin{abstract}
Abstrak
Tujuan penelitian ini adalah untuk mengetahui pengaruh dua pendekatan yaitu saintifik dan Open-ended terhadap kemampuan literasi matematis siswa. Penelitian ini merupakan penelitian kuantitatif yang menggunakan uji komparasi $t$ setelah melalui uji prasyarat yang meliputi uji normalitas dan homogenitas. Sampel yang digunakan yaitu kelas VIII G dan H pada SMP Negeri 1 Kefamenanu. Sebelum diterapkan kedua pendekatan, para siswa diberikan tes awal literasi dan setelah diterapkan kedua pendekatan diberikan tes akhir literasi. Pada hasil penelitian dengan pengujian inferensial diperoleh bahwa pengaruh penerapan pendekatan saintifik terhadap kemampuan literasi sebesar 17,1\% dan pengaruh pendekatan open-endeed sebesar $11,6 \%$. Hal ini menunjukkan bahwa kedua pendekatan ini sama-sama memberikan pengaruh positif terhadap kemampuan literasi matematika.
\end{abstract}

Kata kunci: Literasi matematis; open-ended ; pendekatan; saintifik

\begin{abstract}
This research aims at determining the effect of two approaches namely Scientific and Open-ended toward the students'ability on mathematical literacy. This research is a quantitative study using the comparative $t$ test after passing the prerequisite test for normality and homogeneity. The sample used was the students in second grade of Junior High School in SMP Negeri I Kefamenanu in both class G and H. Before both approaches were applied, the students in each class were given the pre-test of literacy as well as the posttest of literacy after both approaches were applied. The result using inferential test shows that the effect of Scientific approach toward students 'ability on literacy was 17,1\% shile for Open-endeed approaches was 11,6\%. This defines that both approaches have positive effecttoward the ability of mathematical literacy.
\end{abstract}

Keywords: Approach; mathematics literation; open-ended; scientific.

This is an open access article under the Creative Commons Attribution 4.0 International License

\section{PENDAHULUAN}

Literasi merupakan kemampuan mengolah dan memahami informasi yang terintegrasi dalam proses membaca dan menulis. Literasi selanjutnya berkembang menjadi sesuatu hal yang memiliki arti luas. Dalam dunia matematika dikenal pula istilah literasi matematika yang berarti juga merupakan merumuskan, menggunakan dan menafsirkan yang digunakan dalam penyelesaian masalah matematika (Mansur, 2018).

Kemampuan literasi matematika merupakan salah satu kemampuan yang harus dimiliki oleh siswa. Namun, pada kenyataannya, kemampuan literasi anak Indonesia masih jauh di bawah standar 
jika dibandingkan dengan anak di negara lain. Hal ini didasarkan dari data hasil studi PISA tahun 2018 yang menunjukkan peringkat Indonesia untuk kemampuan matematika berada pada peringkat 73 dari 79 negara yang menjadi partisipan PISA (Hewi \& Shaleh, 2020). Selain itu terdapat pula penelitian sebelumnya yang menyatakan rendahnya kemampuan literasi siswa juga disebabkan karena belum terbiasanya mengerjakan soal PISA (S \& Rosalina, 2019) dan juga rendahnya kemampuan pemecahan masalah matematis siswa (Mariam et al., 2018). Oleh karena itu, para praktisi pendidikan mulai memikirkan cara untuk mengejar peringkat dalam kemampuan literasi sehingga dapat setara dengan negara lain. Salah satu cara yaitu dengan meningkatkan kualitas pengajaran yang pada umumnya diterapkan berdasarkan hasilhasil penelitian mengenai peningkatan kemampuan literasi.

Berdasarkan hasil wawancara dengan salah satu guru mata pelajaran matematika di SMP Negeri 1 Kefamenanu, bahwa kemampuan literasi khususnya literasi matematis siswa masih sangat rendah. Hal ini diperkuat oleh hasil pekerjaan siswa pada saat guru tersebut memberikan soal HOT dan soal yang diadopsi dari soal PISA. Hal serupa juga dibenarkan oleh koordinator MGMP (Musyawarah Guru Mata Pelajaran) Matematika untuk wilayah Kabupaten Timor Tengah Utara yakni sebagian besar siswa SMP di kabupaten TTU memiliki kemampuan literasi yang masih kurang terutama literasi matematis.

Kemampuan literasi juga menjadi salah satu indikator dari pembentukan karakter dan berpikir tingkat tinggi (Kusumawardani et al., 2018). Dalam menyelesaikan soal-soal yang tergolong dalam high order thingking diperlukan kemampuan literasi yang baik untuk memahami maksud soal dan menyelesaikan soal. HOTS memiliki kaitan yang erat dengan kemampuan literasi, dimana kedua kemampuan ini tidak hanya pada perhitungan matematis namun terdapat unsur penerapan matematika dalam memecahkan masalah kehidupan sehari hari (Dinni, 2018).

Dalam implementasi K13, salah satu pendekatan yang digunakan adalah pendekatan Scientific. Pendekatan ini memiliki karakter yang sesuai dengan teori belajar kontruktivisme yang mana siswa dituntut lebih aktif dalam proses belajar mengajar di kelas (Deswita \& Kusumah, 2018). Dalam pengaplikasiannya, pendekatan ini menggiring siswa untuk menemukan konsep yang menjadi tujuan pembelajaran (Kamal, 2015). Pendekatan scientific juga berpengaruh positif terhadap kemampuan literasi sains siswa SMP (Alok Irma Suryani, Jufri, A.W, 2017). Pada pendekatan ini siswa melakukan serangkaian kegiatan yang nantinya akan menghantar para siswa memperoleh kesimpulan yang berkaitan dengan konsep yang harus dimengerti siswa.

Selain pendekatan scientific, adapula pendekatan open-endeed yang juga bersesuaian dengan teori belajar kontruktivisme. Pendekatan openendeed dapat menstimulus kemampuan berfikir kritis siswa (Novtiar \& Aripin, 2017) dimana hal ini menjadi salah satu komponen pencapaian dari kurikulum 2013. Pada penerapan pendekatan ini, siswa siswa diberikan serangkaian pernyataan atau pertanyaan yang memiliki jawaban lebih dari satu. Hal ini dapat memunculkan kreatifitas siswa dalam menyelesaikan soal (Sholikhah et al., 2018). Pertanyaan yang diajukan juga merangsang daya berfikir siswa yang tidak hanya memikirkan satu 
kemungkinan jawaban, tetapi juga memikirkan pertanyaan baru dan jawaban baru yang muncul dan masih berkaitan dengan konsep yang harus dimengerti. Hal ini juga sejalan dengan hasil penelitian yang menyatakan bahwa melalui pendekatan Open-endeed dapat membantu siswa untuk lebih mengasah kreatifitas dalam memecahkan problemsolving yang terkait dengan literasi matematika (Aminah et al., 2019).

Berdasarkan uraian tersebut, penelitian ini dimaksudkan untuk melihat apakah penerapan pendekatan Scientific dan Open-ended mempunyai pengaruh atau efek terhadap kemampuan literasi matematika siswa secara khusus pada salah satu SMP di kota kabupaten Kefamenanu. Setelah melihat pengaruh dari kedua pendekatan ini, dilanjutkan dengan membandingkan pengaruh mana yang lebih baik. Kedua pendekatan ini dianggap sesuai dengan kurikulum 2013 yang diterapkan pada sekolah tersebut.

\section{METODE PENELITIAN}

Penelitian ini dilaksanakan SMP Negeri 1 Kefamenanu pada semester ganjil 2020/2021. Penelitian ini merupakan penelitian kuantitatif, dengan dua jenis perlakuan yang diberikan yaitu: Pendekatan Scientific dan Pendekatan Open-Ended. Dilakukan pada dua kelas dengan pengambilan sampel secara random. Dua kelas yang terpilih adalah kelas VIII G sejumlah 23 orang dan kelas VIII H sejumah 31 orang. Adapun variabel dalam penelitian ini adalah kemampuan literasi matematika siswa kelas VIII SMP Negeri 1 Kefamenanu setelah diterapkan Pendekatan Scientific dan Pendekatan Open-Ended sebagai dua variabel bebas.

Instrumen yang akan digunakan untuk mengumpulkan data adalah tes kemampuan literasi matematika. Tes disusun berdasarkan indikator literasi matematis. Instrumen tersebut divalidasi secara konten oleh ahli yang merupakan teman sejawat penelitian pada program studi Pendidikan Matematika FIP Unimor. Instrumen untuk melihat kemampuan literasi diperoleh dari instrumen yang sudah ada berdasarkan hasil penelitian yang relevan. Selain itu instrumen literasi ini juga diuji secara empiris melalui pengujian validitas dan reliabilitas. Dalam penelitian ini, diterapkan dua pendekatan yang nantinya menggunakan perangkat pembelajaran sesuai dengan langkahlangkah kedua pendekatan tersebut.

Selain tes literasi, terdapat pula sejumlah perangkat pembelajaran yang dibuat berdasarkan pendekatan saintifik dan pendekatan open-ended. Perangkat pembelajaran tersebut terdiri dari RPP, bacaan terkait materi yang dipelajari, lembar kerja siswa, gambar-gambar yang digunakan pada saat simulasi, lembar respon siswa dan lembar observasi keterlaksanaan pembelajaran baik ditinjau dari guru dan siswa.

Desain penelitian yang akan digunakan adalah pre-test post-test control design. Dalam desain ini terdapat dua kelas eksperimen. Kedua kelas tersebut diberi perlakuan berupa pengajaran dengan Pendekatan Scientific dan Pendekatan Open-Ended kemudian secara inferensial data hasil belajar yang merupakan kemampuan literasi siswa diuji apakah Pendekatan Scientific lebih mempengaruhi literasi siswa dibandingkan Pendekatan OpenEnded atau tidak. Dari penelitian ini akan dilihat seberapa besar pengaruh penerapan Pendekatan Scientific dan Pendekatan Open-Ended terhadap kemampuan litersi siswa serta manakah dari dua pendekatan tersebut yang lebih berpengaruh. Skema desain penelitian disajikan dalam Gambar 1. 
DOI: https://doi.org/10.24127/ajpm.v10i2.3562

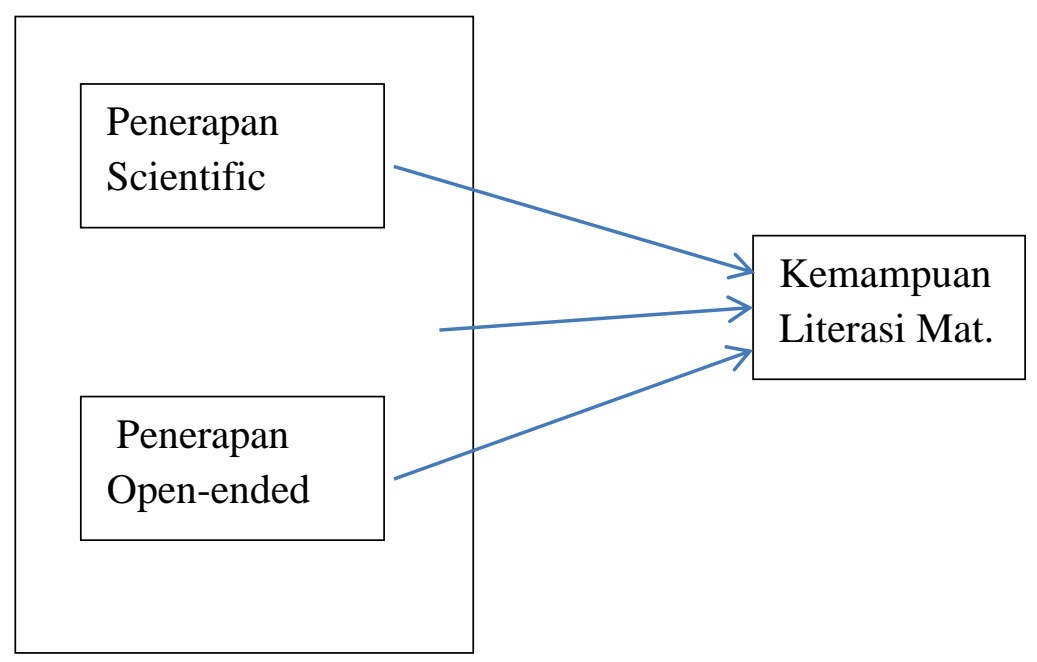

Sumber: Sugiyono (2012)

Gambar 1 Desain penelitian

Keterangan: $\longrightarrow$ (Pengaruh)

Adapun data yang diperlukan dalam penelitian ini yaitu, data kemampuan literasi matematika yang diperoleh dari instrumen literasi yang sudah ada berdasarkan hasil penelitian yang relevan. Data keterlaksanaan pembelajaran siswa dan aktivitas siswa diperoleh melalui pengamatan berdasarkan lembar observasi aktivitas siswa yang sesuai dengan kriteria aktivitas siswa dengan Pendekatan Scientific dan Pendekatan Open-Ended. Data respons siswa diperoleh dari pendapat dan tanggapan siswa terhadap pembelajaran dengan menggunakan Pendekatan Scientific dan Pendekatan Open-Ended pada lembar angket respons dan diberikan pada akhir pembelajaran.

\section{HASIL DAN PEMBAHASAN}

Pendekatan saintifik merupakan pendekatan yang sesuai dengan implemetasi dari kurikulum 2013 (Dina et al., 2015). Untuk mengetahui pengaruh pendekatan saintifik terhadap kemampuan literasi dilakukan dengan uji $t$ untuk sampel berpasangan dengan mengambil skor tes awal literasi dan tes akhir literasi yang diberikan kepada siswa kelas VIII G. Sebelum dilakukan uji $t$, dilakukan terlebih dahulu uji prasyarat yaitu uji normalitas (uji homogenitas dan uji linearitas tidak diperlukan karena data berasal dari sampel berpasangan sehingga homogenitas varians tidak perlu diuji dan tidak memerlukan persyaratan linearitas). Hasil uji normalitas selengkapnya terdapat pada Tabel 1 . dan Tabel 2.

Tabel 1. Hasil statistika deskriptif

\begin{tabular}{cccccc}
\hline \multicolumn{7}{c}{ Descriptive Statistics } \\
\hline Scientific & N & Mean & Std. Deviation & Min & Max \\
\hline & 23 & 18.0317 & 9.35421 & 3.30 & 33.70 \\
\hline
\end{tabular}


DOI: https://doi.org/10.24127/ajpm.v10i2.3562

Tabel 2. Hasil SPSS uji normalitas

\begin{tabular}{|c|c|c|}
\hline \multicolumn{3}{|c|}{ One-Sample Kolmogorov-Smirnov Test } \\
\hline & & \\
\hline \multicolumn{2}{|l|}{$\mathrm{N}$} & 23 \\
\hline Normal & Mean & 18.0317 \\
\hline Parameters ${ }^{\mathrm{a}, \mathrm{b}}$ & Std. Deviation & 9.35421 \\
\hline \multirow{3}{*}{$\begin{array}{l}\text { Most Extreme } \\
\text { Differences }\end{array}$} & Absolute & .120 \\
\hline & Positive & .098 \\
\hline & Negative & -.120 \\
\hline \multicolumn{2}{|c|}{ Kolmogorov-Smirnov Z } & .575 \\
\hline \multicolumn{2}{|c|}{ Asymp. Sig. (2-tailed) } & .895 \\
\hline
\end{tabular}

a. Test distribution is Normal.

b. Calculated from data.

Berdasarkan Tabel 1, dapat dilihat ukuran pemusatan datanya berada pada rata-rata 18,0317 , standar deviasi 9,35 sedangkan Uji normalitas yang digunakan yaitu Uji KolmogorovSmirnov yang tertera pada Tabel 2. memberikan hasil Asymp Sig (2-tailed) yaitu 0.895 lebih besar dari 0.05 sehingga dapat disimpulkan data tersebut berdistribusi normal. Kemudian analisis dilanjutkan untuk mengetahui apakah Pendekatan Saintifik berpengaruh pada kemampuan literasi siswa. Pengujian memanfaatkan Uji $t$ yang dapat dilihat pada Tabel 3 yang meliputi hasil paired samples statistics, paired samples correlation, dan paired samples test.

Tabel 3. Hasil SPSS uji t penerapan pendekatan saintifik

Paired Samples Statistics

\begin{tabular}{llcccc}
\hline & & Mean & N & Std. Deviation & Std. Error Mean \\
\hline Pair & SkorAwalSc & 9.5552 & 23 & 7.67584 & 1.60052 \\
1 & SkorAkhirSc & 27.0043 & 23 & 10.93956 & 2.28106 \\
\hline
\end{tabular}

Paired Samples Correlations

\begin{tabular}{llccc}
\hline & & N & Correlation & Sig. \\
\hline Pair 1 & SkorAwalSc \& SkorAkhirSc & 23 & .414 & .050 \\
\hline
\end{tabular}

\section{Paired Samples Test}

\begin{tabular}{|c|c|c|c|c|c|c|c|c|c|}
\hline & & \multirow[t]{2}{*}{ Mean } & \multirow[t]{2}{*}{$\begin{array}{c}\text { Std. } \\
\text { Deviation }\end{array}$} & \multirow{2}{*}{$\begin{array}{l}\text { Std. } \\
\text { Error } \\
\text { Mean }\end{array}$} & \multicolumn{2}{|c|}{$\begin{array}{l}\text { 95\% Confidence } \\
\text { Interval of the } \\
\text { Difference }\end{array}$} & \multirow[t]{2}{*}{$\mathbf{T}$} & \multirow[t]{2}{*}{ df } & \multirow{2}{*}{$\begin{array}{c}\text { Sig. } \\
(2- \\
\text { tailed) }\end{array}$} \\
\hline & & & & & Lower & Upper & & & \\
\hline $\begin{array}{l}\text { Pair } \\
1\end{array}$ & $\begin{array}{l}\text { SkorAwalSc } \\
\text { SkorAkhirSc }\end{array}$ & ${ }^{-}-17.44913$ & 10.44569 & 2.17808 & -21.96618 & -12.93208 & -8.011 & 22 & .000 \\
\hline
\end{tabular}

Berdasarkan Tabel 3, diperoleh bahwa nilai Sig (2-tailed) yaitu $0.000<$ 0.05 (tingkat signifikasi yang ditetapkan) sehingga dapat disimpulkan bahwa nilai pretest lebih rendah dibandingkan nilai posttest atau penerapan Pendekatan Saintifik berpengaruh positif terhadap kemampuan literasi matematis siswa. Selanjutnya, Tabel 4 menggambarkan seberapa besar Pendekatan Saintifik berpengaruh positif terhadap kemampuan literasi matematis siswa. 
DOI: https://doi.org/10.24127/ajpm.v10i2.3562

Tabel 4. Besar pengaruh pendekatan saintifik

Measures of Association

\begin{tabular}{lcccc}
\hline & R & R Squared & Eta & Eta Squared \\
\hline SkorAkhirSc * SkorAwalSc & .414 & $\mathbf{. 1 7 1}$ & .801 & .641 \\
\hline
\end{tabular}

Tabel 4. secara spesifik menunjukkan seberapa besar pengaruh Pendekatan Saintifik terhadap kemampuan literasi matematir siswa. Terlihat bahwa $R$ squared yang dihasilkan yaitu 0.171 sehingga dapat disimpulkan bahwa Pendekatan Saintifik berpengaruh terhadap kemampuan literasi matematis siswa sebesar $17,1 \%$

Selajan dengan Pendekatan Saintifik, pada penerapan pendekatan Open-Ended dilakukan kepada peserta didik kelas VIII H. Uji $t$ untuk sampel

Tabel 5. Hasil statistika deskriptif

Descriptive Statistics

\begin{tabular}{lccccc}
\hline & N & Mean & Std. Deviation & Minimum & Maximum \\
\hline OpenEnded & 31 & $\mathbf{1 8 . 9 3 8 7}$ & $\mathbf{8 . 3 6 9 4 2}$ & 3.30 & 33.40 \\
\hline
\end{tabular}

Tabel 6. Hasil uji normalitas untuk open-ended

One-Sample Kolmogorov-Smirnov Test

\begin{tabular}{llr}
\hline & & OpenEnded \\
\hline N & & 31 \\
& Mean & 18.9387 \\
& Std. Deviation & 8.36942 \\
Most Extreme Differences & Absolute & .127 \\
& Positive & .127 \\
Kolmogorov-Smirnov Z & Negative & -.126 \\
Asymp. Sig. (2-tailed) & & .707 \\
\hline
\end{tabular}

a. Test distribution is Normal.

b. Calculated from data.

Hasil pada Tabel 5. menunjukkan bahwa ukuran pemusatan datanya berada pada rata-rata 18,9387 dan standar deviasi 8,36. Hasil Uji normalitas pada Tabel 6. yang memanfaatkan Uji KolmogorovSmirnov memberikan hasil Asymp Sig (2-tailed) yaitu 0.700 lebih besar dari berpasangan dengan mengambil skor tes awal literasi dan tes akhir literasi yang diberikan kepada siswa kelas VIII G. Sebelum dilakukan uji $t$, dilakukan terlebih dahulu uji prasyarat yaitu uji normalitas (uji homogenitas dan uji linearitas tidak diperlukan karena data berasal dari sampel berpasangan sehingga homogenitas varians tidak perlu diuji dan tidak memerlukan persyaratan linearitas). Hasil uji normalitas selengkapnya terdapat pada Tabel 5 dan Tabel 6. 
DOI: https://doi.org/10.24127/ajpm.v10i2.3562

Tabel 7. Hasil uji t untuk open-ended

\begin{tabular}{llcccc}
\multicolumn{6}{c}{ Paired Samples Statistics } \\
\hline & & Mean & N & Std. Deviation & Std. Error Mean \\
\hline Pair & SkorAwalOE & 11.8871 & 31 & 5.23977 & .94109 \\
1 & SkorAkhirOE & 30.3935 & 31 & 9.69202 & 1.74074 \\
\hline
\end{tabular}

Paired Samples Correlations

\begin{tabular}{llccc}
\hline & & N & Correlation & Sig. \\
\hline Pair 1 & SkorAwalOE \& SkorAkhirOE & 31 & .341 & .061 \\
\hline
\end{tabular}

\section{Paired Samples Test}

\begin{tabular}{|c|c|c|c|c|c|c|c|c|c|}
\hline & & \multirow[t]{2}{*}{ Mean } & \multirow[t]{2}{*}{$\begin{array}{c}\text { Std. } \\
\text { Deviation }\end{array}$} & \multirow{2}{*}{$\begin{array}{l}\text { Std. } \\
\text { Error } \\
\text { Mean }\end{array}$} & \multicolumn{2}{|c|}{$\begin{array}{l}\text { 95\% Confidence } \\
\text { Interval of the } \\
\text { Difference }\end{array}$} & \multirow[t]{2}{*}{$\mathbf{T}$} & \multirow[t]{2}{*}{ df } & \multirow{2}{*}{$\begin{array}{l}\text { Sig. } \\
(2- \\
\text { tailed) }\end{array}$} \\
\hline & & & & & Lower & Upper & & & \\
\hline $\begin{array}{l}\text { Pair } \\
1\end{array}$ & $\begin{array}{l}\text { SkorAwalOE - } \\
\text { SkorAkhirOE }\end{array}$ & -18.50645 & 9.31518 & 1.67306 & -21.92329 & -15.08962 & -11.061 & 30 & .000 \\
\hline
\end{tabular}

Berdasarkan Tabel 7 diperoleh bahwa nilai Sig (2-tailed) yaitu 0.000 kurang dari 0.05 (tingkat signifikasi yang ditetapkan) sehingga dapat disimpulkan bahwa nilai pretest lebih rendah dibandingkan nilai posttest atau dapat dikatakan bahwa penerapan pendekatan Open-Ended memberikan pengaruh positif terhadap kemampuan literasi matematis siswa. Selanjutnya pada Tabel 8 akan ditunjukkan seberapa besar pendekatan Open-Ended berpengaruh positif terhadap kemampuan literasi matematis siswa. .

Tabel 8. Besar pengaruh penerapan open-ended

Measures of Association

\begin{tabular}{rrrrr}
\hline & R & R Squared & \multicolumn{1}{c}{ Eta } & \multicolumn{1}{c}{ Eta Squared } \\
\hline SkorAkhirOE * SkorAwalOE & .341 & $\mathbf{. 1 1 6}$ & .700 & .490 \\
\hline
\end{tabular}

Terlihat pada Tabel 8. R squared yang dihasilkan yaitu 0.116 sehingga dapat disimpulkan bahwa pendekatan Open-Ended berpengaruh terhadap kemampuan literasi matematis siswa sebesar $11.6 \%$. Untuk memperdalam hasil analisis maka dilakukan analisis perbandingan penerapan Pendekatan Saintifik dan Pendekatan Open-Ended dalam mempengaruhi kemampuan literasi siswa kelas VII SMP Negeri 1
Kefamenanu. Pengujian dilakukan dengan memanfaatkan Uji $t$ untuk 2 populasi independen dengan sampel kecil. Untuk itu terlebih dahulu akan dilakukan uji prasyarat yaitu uji normalitas hasil Posttest kedua pendekatan dan uji homogenitas sebelum dilakukan uji $t$ yang telah disebutkan sebelumnya. Tabel 9 dan Tabel 10 akan memperlihatkan hasil pengujian normalitas.

Tabel 9. Hasil statistika deskriptif

\section{Descriptive Statistics}

\begin{tabular}{lccccc}
\hline & $\mathrm{N}$ & Mean & Std. Deviation & Minimum & Maximum \\
\hline SkorAkhirSc & 23 & $\mathbf{2 7 . 0 0 4 3}$ & $\mathbf{1 0 . 9 3 9 5 6}$ & 8.00 & 48.70 \\
SkorAkhirOE & 31 & $\mathbf{3 0 . 3 9 3 5}$ & $\mathbf{9 . 6 9 2 0 2}$ & 10.00 & 46.70 \\
\hline
\end{tabular}


DOI: https://doi.org/10.24127/ajpm.v10i2.3562

Tabel 10. Hasil Uji Normalitas untuk skor Awal dan Akhir kedua Pendekatan One-Sample Kolmogorov-Smirnov Test

\begin{tabular}{|c|c|c|c|}
\hline & & SkorAkhirSc & SkorAkhirOE \\
\hline $\mathrm{N}$ & & 23 & 31 \\
\hline \multirow{2}{*}{ Normal Parameters ${ }^{\mathrm{a}, \mathrm{b}}$} & Mean & 27.0043 & 30.3935 \\
\hline & Std. Deviation & 10.93956 & 9.69202 \\
\hline \multirow{3}{*}{$\begin{array}{l}\text { Most Extreme } \\
\text { Differences }\end{array}$} & Absolute & .134 & .134 \\
\hline & Positive & .114 & .096 \\
\hline & Negative & -.134 & -.134 \\
\hline \multicolumn{2}{|l|}{ Kolmogorov-Smirnov Z } & .642 & .746 \\
\hline \multicolumn{2}{|l|}{ Asymp. Sig. (2-tailed) } & .805 & .634 \\
\hline
\end{tabular}

a. Test distribution is Normal.

b. Calculated from data.

Berdasarkan Tabel 9. terlihat bahwa ukuran pemusatan data antara dua pendekatan tidak berbeda jauh. Pendekatan Saintifik menghasilkan nilai rata-rata 27.0043 dan 30.3935 untuk pendekatan Open-Ended. Hal yang sama juga berlaku pada Standar deviasi dimana Pendekatan Saintifik menghasilkan standar deviasi 10.9395 dan 9.69202 untuk pendekatan OpenEnded. Uji normalitas yang digunakan yaitu Uji Kolmogorov-Smirnov yang memberikan hasil masing-masing Asymp Sig (2-tailed) yang lebih besar dari 0.05 sehingga dapat disimpulkan data tersebut berdistribusi normal. Uji Prasyarat dilanjutkan dengan menguji asumsi berikutnya yaitu Homogenitas data. Hasil uji homogenitas menggunakan SPSS disajikan dalam Tabel 11.

Tabel 11. Uji homogenitas untuk kedua pendekatan

Test of Homogeneity of Variances

Posttest

\begin{tabular}{cccc}
\hline Levene Statistic & df1 & df2 & Sig. \\
\hline .214 & 1 & 52 & $\mathbf{. 6 4 6}$ \\
\hline
\end{tabular}

Berdasarkan pengujian untuk Uji Homogenitas pada Tabel 11 diperoleh nilai Sig yaitu 0.646 yang lebih dari 0.05 sehingga dapat disimpulkan bahwa data kemampuan literasi siswa setelah diberikan pembelajaran menggunakan kedua pendekatan tersebut bersifat Homogen. Oleh karena itu pengujian akan dilanjutkan dengan Uji $t$ untuk 2 populasi independen. Hasil pengujiannya dapat dilihat pada Tabel 12.

Berdasarkan data pada Tabel 12, terlihat bahwa nilai Sig (2-tailed) 0.234 yang lebih besar dari 0.05 sehingga dapat disimpulkan bahwa $H_{0}$ diterima atau Pendekatan Saintifik tidak lebih berpengaruh pada kemampuan literasi matematika siswa kelas VII SMP Negeri 1 Kefamenanu dibanding Pendekatan Open-Ended. Hal ini memberikan arti bahwa Pendekatan Saintifik dan Pendekatan Open-Ended sama-sama mempengaruhi kemampuan literasi matematika siswa kelas VII SMP Negeri 1 Kefamenanu. 
DOI: https://doi.org/10.24127/ajpm.v10i2.3562

Tabel 12. Hasil Uji t Sampel bebas Untuk kedua Pendekatan

\begin{tabular}{|c|c|c|c|c|c|c|c|c|c|c|}
\hline \multicolumn{11}{|c|}{ Independent Samples Test } \\
\hline & & \multirow{3}{*}{\multicolumn{2}{|c|}{$\begin{array}{c}\text { Levene's } \\
\text { Test for } \\
\text { Equality of } \\
\text { Variances }\end{array}$}} & \multirow{3}{*}{\multicolumn{7}{|c|}{ t-test for Equality of Means }} \\
\hline & & & & & & & & & & \\
\hline & & & & & & & & & & \\
\hline & & \multirow[t]{2}{*}{$\mathrm{F}$} & \multirow[t]{2}{*}{ Sig. } & \multirow[t]{2}{*}{$\mathrm{t}$} & \multirow[t]{2}{*}{ Df } & \multirow[t]{2}{*}{$\begin{array}{l}\text { Sig. } \\
(2- \\
\text { tailed) }\end{array}$} & \multirow[t]{2}{*}{$\begin{array}{l}\text { Mean } \\
\text { Differen } \\
\text { ce }\end{array}$} & \multirow[t]{2}{*}{$\begin{array}{l}\text { Std. Error } \\
\text { Difference }\end{array}$} & \multicolumn{2}{|c|}{$\begin{array}{l}\text { 95\% Confidence } \\
\text { Interval of the } \\
\text { Difference }\end{array}$} \\
\hline & & & & & & & & & Lower & Upper \\
\hline \multirow{3}{*}{$\begin{array}{l}\text { Posttes } \\
\mathrm{t}\end{array}$} & $\begin{array}{l}\text { Equal } \\
\text { variances } \\
\text { assumed }\end{array}$ & .214 & .646 & -1.203 & 52 & .234 & -3.38920 & 2.8176 & -9.04319 & 2.26479 \\
\hline & Equal & & & & & & & & & \\
\hline & $\begin{array}{l}\text { variances } \\
\text { not } \\
\text { assumed }\end{array}$ & & & -1.181 & 44.114 & .244 & -3.38920 & 2.8693 & -9.17165 & 2.39325 \\
\hline
\end{tabular}

Beberapa penelitian terdahulu menyebutkan bahwa melalui Pendekatan Saintifik yang diterapkan dalam bahan ajar, dapat meningkatkan kemampuan literasi siswa (Mardiana, 2018). Adapula hasil penelitian lainnya menyatakan bahwa pendekatan openended mempunyai pengaruh yang positif terhadap kemampuan penalaran siswa, dimana kemampuan penalaran ini juga salah satu kemampuan yang erat kaitannya dengan literasi matematika (Lestari et al., 2016). Sejalan dengan penelitian mengenai pendekatan saintifik juga menyebutkan bahwa terdapat pengaruh positif pendekatan ini dengan kemampuan berpikir tingkat tinggi dan pemecahan masalah (Erny et al., 2017), yang mana kedua kemampuan ini juga termuat dalam soal-soal PISA.

Dalam hasil penelitian ini, diperoleh pengaruh positif dari penerapan baik pendekatan saintifik maupun open-endeed terhadap kemampuan literasi yang sangat kecil yaitu masing-masing $17,1 \%$ dan $11,6 \%$. Hal ini menimbulkan pemikiran bagi peneliti bahwa dalam suatu proses pembelajaran mungkin tidak hanya menitikberatkan pada pendekatan saja, namun harus dibarengi oleh penerapam model, metode dan juga strategi yang baik sehingga dapat lebih meningkatkan kemampuan literasi siswa. Tidak menutup kemungkinan hal tersebut dapat dijadikan bahan untuk penelitian selanjutnya.

\section{KESIMPULAN DAN SARAN}

Berdasarkan hasil penelitian diperoleh kesimpulan yaitu penerapan pendekatan Scientific berpengaruh positif terhadap kemampuan literasi matematis siswa kelas VIII SMP Negeri 1 Kefamenanu. Penerapan pendekatan Open-Ended juga berpengaruh positif terhadap kemampuan literasi matematis siswa kelas VIII SMP Negeri 1 Kefamenanu. Pendekatan Scientific dan Pendekatan Open-Ended sama-sama mempengaruhi kemampuan literasi matematika siswa kelas VII SMP Negeri 1 Kefamenanu.

Berdasarkan hasil yang diperoleh bahwa kedua pendekatan baik itu OpenEnded maupun penekatan Saintifik mempunyai pengaruh positif terhadap kemampuan literasi matematika siswa. Oleh karenya, disarankan kepada guru khususnya guru Mapel Matematika sebaiknya menggunakan kedua 
pendekatan ini dalam proses pembelajaran matematika. Selain memberikan keberagaman pendekatan yang digunakan, juga sebagai salah satu alternatif dalam meningkatkan kemampuan literasi matematis siswa.

Penelitian ini masih belum sempurna sehingga terbuka kemungkinan bagi peneliti lain untuk mengeksplor lebih jauh mengenai pendekatan lain yang dapat digunakan untuk meningkatkan kemampuan literasi matematis siswa. Penelitian lain mengenai literasi data juga masih sangat memungkinkan untuk dilakukan mengingat peneliti disini hanya membahas kemampuan literasi matematis secara umum. Selain itu, disarankan untuk melakukan penelitian selanjutnya tidak hanya menerapkan pendekatan saja, namun harus disertai model, metode ataupun startegi dalam proses belajar mengajar sehingga diharapkan kemampuan literasi siswa dapat ditingkatkan.

\section{DAFTAR PUSTAKA}

Alok Irma Suryani, Jufri, A.W, D. S. (2017). Pengaruh Model Pembelajaran 5E Terintegrasi Pendekatan Saintifik terhadap Kemampuan Literasi Sains Siswa SMPN 1 Kuripan Tahun Aajaran 2016/2017. Pijar MIPA, XII(1), 39-43.

Aminah, S., Dwiyati, N. K., \& Mulyono. (2019). Kemampuan Literasi Matematika Ditinjau dari Kreativitas Melalui Pendekatan Open Ended Problems ( OEP ). Prisma, Prosicing Seminar Nasional Matematika, 2, 51-57. https://journal.unnes.ac.id/sju/inde x.php/prisma/article/view/28865

Deswita, R., \& Kusumah, Y. S. (2018). Peningkatan Kemampuan Komunikasi Matematis Siswa
Melalui Model Pembelajaran CORE dengan Pendekatan Scientific. Edumatika: Jurnal Riset Pendidikan Matematika, 1(1), 35. https://doi.org/10.32939/ejrpm.v1i 1.220

Dina, A., Mawarsari, V. D., \& Suprapto, R. (2015). Implementasi kurikulum 2013 pada perangkat pembelajaran model discovery learning pendekatan scientific terhadap kemampuan komunikasi matematis materi geometri SMK. Jurnal Karya Pendidikan Matematika, 2(1), 22-31.

Dinni, H. N. (2018). HOTS ( High Order Thinking Skills ) dan Kaitannya dengan Kemampuan Literasi Matematika. PRISMA, Prosiding Seminar Nasional Matematika, 1, 170-176. https://journal.unnes.ac.id/sju/inde x.php/prisma/\%0AHOTS

Hewi, L., \& Shaleh, M. (2020). Refleksi Hasil PISA (The Programme For International Student Assesment): Upaya Perbaikan Bertumpu Pada Pendidikan Anak Usia Dini). Jurnal Golden Age, 4(01), 30-41. https://doi.org/10.29408/jga.v4i01 .2018

Kamal, S. (2015). Implementasi pendekatan scientific untuk meningkatkan kemandirian belajar matematika. Math Didactic: Jurnal Pendidikan Matematika, 1(1), 56-64. https://doi.org/10.33654/math.v1i 1.95

Kusumawardani, D. R., Wardono, \& Kartono. (2018). Pentingnya Penalaran Matematika dalam Meningkatkan Kemampuan Literasi Matematika. Prisma, 1(1), 588-595. 
Lestari, N., Hartono, Y., \& Porwoko. (2016). Matematika Siswa Sekolah Menengah Pertama Palembang Neny Lestari, Yusuf Hartono , dan Purwoko. Jurnal Pendidikan Matematika, 10(1), 81-95.

Mansur, N. (2018). Melatih Literasi Matematika Siswa dengan Soal PISA. Prisma, 1, 140-144. https://journal.unnes.ac.id/sju/inde x.php/prisma/\%0AMelatih

Mardiana, E. (2018). Pengembangan Bahan Ajar Berbasis Pendekatan Saintifik Meningkatkan Kemampuan Literasi Matematika Siswa Pascasarjana, Universitas Negeri Malang. Prisma, Prosiding Seminar Nasional Matematika, 1, 87-91.

Mariam, S., Rohaeti, E. E., \& Sariningsih, R. (2018). Analisis Kemampuan Pemecahan Masalah Matematis Siswa Madrasah Aliyah pada Materi Pola Bilangan. Journal on Education, 1(2), 156-162.

Novtiar, C., \& Aripin, U. (2017). Meningkatkan Kemampuan Berpikir Kritis Matematis Dan Kepercayaan Diri Siswa Smp Melalui Pendekatan Open Ended. Prisma, 6(2), 119-131. https://doi.org/10.35194/jp.v6i2.1 22

S, A. E., \& Rosalina, E. (2019). Soal Matematika Model PISAMenggunakan Konteks Lubuklinggau. Jurnal Pendidikan Matematika Raflesia, 04(02), 6775.

Sholikhah, Z., Kartana, T. J., \& Utami, W. B. (2018). Efektifitas Model Pembelajaran Open-Ended Terhadap Prestasi Belajar Matematika Ditinjau Dari Kreativitas Siswa. JES-MAT
(Jurnal Edukasi Dan Sains Matematika), 4(1), 35. https://doi.org/10.25134/jesmat.v4i1.908

Suryapuspitarini, B. K., Wardono, \& Kartono. (2018). Analisis SoalSoal Matematika Tipe Higher Order Thinking Skill ( HOTS ) pada Kurikulum 2013 untuk Mendukung Kemampuan Literasi Siswa. Prisma, Prosiding Seminar Nasional Matematika, 1, 876884.

https://journal.unnes.ac.id/sju/inde x.php/prisma/article/view/20393 